\title{
PENGARUH MOTIVASI DAN METODE MENGAJAR TERHADAP PRESTASI MATA KULIAH HADITS MAHASISWA IAIN PADANGSIDIMPUAN
}

\author{
Hj. Tatta Herawati Daulae \\ Dosen Fakultas Tarbiyah dan Ilmu Keguruan IAIN Padangsidimpuan \\ Jl. T. Rizal Nurdin Km. 4.5 Sihitang Padangsidimpuan 22733 \\ Email: tattaherawatie@yahoo.co.id
}

\begin{abstract}
This study has been done to get the overview of learning methods used by the lectures and motivation given by lectures, and the influence to students' learning achievement in Hadist at IAIN Padangsidimpuan. The result shows that the lecturer's motivation and learning methods used in learning Hadits is in the middle category. Then, students' achievement in learning Hadits is good (on the average 76.75 : B). Based on the result, it is shown that the motivation from lecturer and learning method used give the significant contribution to the students' achievement in learning Hadist.
\end{abstract}

Keywords: Motivation, learning Methods, and Learning Achievement

\begin{abstract}
Abstrak
Penelitian ini bertujuan untuk mendapatkan gambaran tentang metode pembelajaran yang di pakai oleh dosen dan gambaran motivasi yang dibuat kepada mahasiswa serta terlihat pengaruh motivasi dan metode pembelajaran terhadap prestasi belajar mata kuliah Hadits Mahasiswa IAIN Padangsidimpuan. Dari hasil penelitian ini diperoleh bahwa Motivasi dari dosen mata kuliah Hadits termasuk dalam kategori sedang dengan dan metode mengajar dosen juga termasuk kategori sedang. Sedangkan prestasi mata kuliah Hadits mahasiswa IAIN Padangsidimpuan masuk kategori Baik dengan rata-rata perolehan nilai 76,75 (kategori nilai B). Temuan penelitian ini memperlihatkan bahwa motivasi dari dosen dan metode mengajar dosen baik secara sendiri-sendiri maupun secara bersama-sama mempunyai pengaruh yang signifikan terhadap prestasi mahasiswa dalam mata kuliah Hadits.
\end{abstract}

Kata Kunci: Motivasi, Metode dan Prestasi Belajar

\section{PENDAHULUAN}

Prestasi belajar yang baik menjadi harapan bagi setiap orang, baik penyelenggara pendidikan, pemerintah maupun masyarakat. Lembaga pendidikan adalah salah satu tempat pencapaian prestasi belajar, menyiapkan peserta didik agar memiliki ilmu pengetahuan dan mampu menghadapi permasalahan yang dihadapinya. Hal ini sangat tergantung pada peran guru atau dosen. 
Penyelenggara pendidikan di sekolah, terletak pada pundak guru atau dosen. Berbagai kebijakan dan upaya-upaya pembaharuan yang telah diambil dalam bidang pendidikan terletak pada dosen sebagai pengelola pembelajaran. Dosen sebagai pengelola pembelajaran bertanggung jawab mengatur, mengarahkan dan menciptakan suasana belajar. Seluruh kegiatan pembelajaran terletak pada dosen.

Pembelajaran merupakan suatu proses yang kompleks dan melibatkan berbagai aspek yang saling berkaitan. Pembelajaran melahirkan interaksi yang bernilai edukatif dan merupakan suatu proses dalam rangka mencapai tujuan pembelajaran. Dosen dengan sadar berusaha mengatur lingkungan belajar agar bergairah bagi mahasiswa. Dengan perangkat teori dan pengalaman, digunakan oleh dosen untuk mempersiapkan pembelajaran dengan baik dan sistematis.

Dalam pembelajaran ada beberapa factor yang dapat meningkatan prestasi belajar, antara lain menggunakan motivasi dan metode yang bervariasi. Hal ini sesuai dengan pendapat Mulyasa, bahwa "Motivasi merupakan salah satu factor yang dapat meningkatkan kualitas pembelajaran". ${ }^{1}$ Karena peserta didik akan belajar dengan sungguh-sungguh, apabila memiliki motivasi yang sangat tinggi. Oleh karena itu untuk meningkatkan kualitas pembelajaran, harus mampu membangkitkan motivasi belajar sehingga dapat mencapai tujuan pembelajaran.

Motivasi inilah yang mendorong mereka untuk melakukan suatu kegiatan belajar. Hasil belajar akan menjadi optimal kalau ada motivasi, makin tepat motivasi yang diberikan, akan makin berhasil pula."Jadi motivasi akan senantiasa melakukan intensitas usaha belajar". ${ }^{2}$ Disamping itu sebagai pendorong usaha dan pencapaian prestasi. ${ }^{3}$

Factor lain dalam meningkatkan prestasi belajar adalah dengan menggunakan metode yang bervariasi. E Mulyasa mengatakan, agar proses pembelajaran dapat dilaksanakan secara efektif dan efesien, serta mencapai hasil yang di harapkan, diperlukan kegiatan manajemen system pembelajaran, ${ }^{4}$ didalamnya termasuk manajemen metodenya.

Prestasi belajar adalah hasil yang dicapai untuk setiap proses pembelajaran pada waktu dan tingkat tertentu. Prestasi belajar yang baik sangat diinginkan oleh semua mahasiswa. Banyak factor yang dapat mendukung tercapainya prestasi belajar yang baik termasuk dosen, motivasi, metode dan komponen-komponen lainnya.

Dosen adalah salah satu komponen yang sangat penting dalam pencapaian hasil belajar. Sebagai komponen yang sangat penting perlu menguasai beberapa pengetahuan, kemampuan dan keterampilan khususnya dalam kajian ini berkaitan dengan motivasi dan metode pembelajaran.

58

${ }^{1}$ E. Mulyasa, Standar Kompetensi dan Sertifikasi Guru, (Bandung: Remaja Rosda Karya, 2007), hlm.

${ }^{2}$ Sardiman, Interaksi dan Motivasi Belajar Mengajar, (Jakarta: Grafindi Persada, 2004), hlm. 85

${ }^{3}$ E. Mulyasa, Guru Profesional Menciptakan Pembelajaran Kreatif dan Menyenangkan, (Bandung: Remaja Rosda Karya, 2007), hlm. 78

${ }^{4}$ Ibid. hlm. 107 
Motivasi dan metode dosen sangat dibutuhkan dalam rangka mewujudkan prestasi yang baik. Didalam perkuliahan, mahasiswa terdiri dari berbagai pribadi yang berbeda satu sama lain, baik perbedaan biologis maupun psikologis. Begitu juga perbedaan pendidikan atau asal sekolah. Perbedaan ini akan mendatangkan masalah dalam menciptakan kondisi belajar yang optimal, oleh sebab itu pemanfaatan motivasi dan metode mengajar yang tepat sangat diperlukan dalam mewujudkan prestasi belajar yang baik.

Adapun perumusan masalah penelitian ini adalah sebagai berikut:

1. Bagaimana gambaran dan metode dosen dalam mengajarkan mata kuliah hadits;

2. Bagaimana pengaruh motivasi yang diberikan oleh dosen terhadap mata kuliah hadits mahasiswa IAIN Padangsidimpuan;

3. Bagaimana pengaruh metode yang dilakukan oleh dosen terhadap prestasi mata kuliah hadits mahasiswa IAIN Padangsidimpuan;

4. Bagaimana pengaruh motivasi dan metode yang diberikan oleh dosen terhadap prestasi mata kuliah hadits mahasiswa IAIN Padangsidimpuan.

\section{KAJIAN PUSTAKA}

Motivasi

a. Pengertian

Secara umum motivasi adalah dorongan yang timbul dalam diri seseorang secara sadar untuk melakukan tindakan-tindakan dengan tujuan tertentu, berarti dengan adanya motivasi menyebabkan seseorang melakukan aktifitas dan tindakan untuk mencapai suatu tujuan.

Menurut S. Nasution, motivasi adalah segala daya yang mendorong seseorang untuk melakukan sesuatu. ${ }^{5}$

Sedangkan menurut Moh Uzer Usman motivasi adalah suatu proses untuk menggiatkan motif-motif untuk menjadi perbuatan atau tingkah laku untuk memenuhi kebutuhan dan mencapai tujuan atau keadaan dan kesiapan dalam diri individu yang mendorong tingkah lakunya untuk berbuat sesuatu dalam mencapai tujuan tertentu. ${ }^{6}$

E. Mulyasa mengutip pendapat Callahan bahwa motivasi adalah tenaga pendorong atau penarik yang menyebabkan adanya tingkah laku kearah tujuan tertentu. ${ }^{7}$

b. Macam-macam Motivasi

Moh Uzer Usman memberikan batasan tentang macam-macam motivasi yaitu motivasi intrinsic dan motivasi ekstrinsik. ${ }^{8}$ Motivasi intrinsic timbul sebagai akibat dari dalam diri individu sendiri tanpa ada paksaan dari orang lain. Tetapi atas kemauan

\footnotetext{
${ }^{5}$ S. Nasution, Didaktik Asas-asas Mengajar, (Bandung: Jammars, 1982), hlm. 76

${ }^{6}$ Moh Uzer Usman, Didaktik Asas-asas Mengajar, (Bandung: Remaja Rosda Karya, 2000), hlm. 28

${ }^{7}$ E. Mulyasa, Op.Cit., hlm. 58

${ }^{8}$ Moh Uzer Usman, Op.Cit., hlm. 29
} 
sendiri. ${ }^{9}$ Misalnya anak mau belajar karena ingin memperoleh ilmu pengetahuan dan ingin menjadi orang yang berguna bagi nusa dan bangsa dan Negara. Oleh karena itu ia rajin belajar tanpa ada suruhan dari orang lain.

Motivasi ekstrinsik timbul sebagai akibat pengaruh dari luar individu, apakah karena ajakan, suruhan ataupun paksaan dari orang lain, sehingga dengan kondiri yang demikian, akhirnya ia mau melakukan sesuatu atau belajar. ${ }^{10}$ Misalnya seorang mau belajar karena ia disuruh oleh orang tuanya agar mendapat peringkat pertama di kelas.

Motivasi dilihat dari dasar pembentukannya:

1) Motif-motif bawaan

Yang dimaksud dengan motif bawaan adalah motif yang dibawa sejak lahir, jadi motivasi itu ada tanpa dipelajari. ${ }^{11}$ Sebagai contoh misalnya: dorongan untuk makan, dorongan untuk minum, dorongan untuk bekerja, untuk beristirahat, dorongan seksual. Motif ini sering kali disebut motif-motif yang diisyaratkan secara biologis.

2) Motif-motif yang dipelajari

Maksudnya motif-motif yang timbul karena dipelajari. Sebagai contoh: dorongan untuk belajar satu cabang ilmu pengetahuan, dorongan untuk mengajar sesuatu di dalam masyarakat. Motif-motid ini sering kali disyari'atkan secara social. ${ }^{12}$ Dalam kegiatan belajar mengajar, hal ini dapat membantu dalam usaha mencapai prestasi.

Ada beberapa ahli yang menggolongkan jenis motivasi itu menjadi dua jenis yakni motivasi jasmaniah dan motivasi rohaniah. Yang termasuk motivasi jasmaniah seperti misalnya: reflex, insting otomatis, nafsu. Sedangkan yang termasuk motivasi rohaniah adalah kemauan.

c. Indikator Motivasi

Para ahli pendidikan memberikan batasan-batasan tentang indicator motivasi. E. Mulyasa mengemukakan prinsip-prinsipnya sebagai berikut:

1) Memberikan tugas yang jelas;

2) Memberikan penghargaan terhadap hasil kerja dan prestasi;

3) Menggunakan hadiah dan hukuman secara efektif dan tepat guna;

4) Memberikan penilaian dengan adil dan transparan. ${ }^{13}$

Moh Uzer mengatakan, bahwa menimbulkan motivasi itu dengan cara:

1) Disertai kehangatan dan keantusiasan;

2) Menimbulkan rasa ingin tahu;
${ }^{9}$ Ibid.
${ }^{10} \mathrm{Ibid}$
${ }^{11} \mathrm{Ibid}$.
${ }^{12} \mathrm{Ibid}$
${ }^{13}$ E. Mulyasa, Standar Kompetensi, Op.Cit., hlm. 59 
3) Mengemukakan ide yang bertentangan;

4) Memperhatikan minat siswa. ${ }^{14}$

Kemudian Moh Uzer Usman menambahkan tentang usaha-usaha guru atau dosen dalam membangkitkan motivasi ekstrinsik dalam menumbuhkan motivasi instrinsik yaitu:

1) Komptensi (persaingan) guru atau dosen harus berusaha menciptakan persaingan, untuk membangkitkan prestasi belajarnya;

2) Pace making (membuat tujuan sementara atau dekat);

3) Tujuan yang jelas yaitu motif mendorong individu untuk mencapai tujuan;

4) Kesempurnaan untuk sukses, kesuksesan dapat menimbulkan rasa puas;

5) Mengadakan penilaian atau tes serta ulangan-ulangan belajar. ${ }^{15}$

Teori motivasi yang ditawarkan Maslow adalah dengan melihat kebutuhan, dalam hal ini ada lima tingkat kebutuhan, maka dari kebutuhan-kebutuhan inilah, hendaknya guru atau dosen dapat memberikan motivasi belajar yaitu kebutuhan untuk aktualisasi diri, kebutuhan untuk di hargai, kebutuhan untuk di akui, kebutuhan akan rasa aman dan kebutuhan psikologis. ${ }^{16}$

\section{Metode Belajar}

a. Pengertian

Metode berasal dari dua kata yaitu Meta dan Hodos. Meta berarti melalui dan hodos berarti jalan atau acara, metode berarti suatu jalan yang dilalui untuk mencapai suatu tujuan. ${ }^{17}$ Syaiful Bukri mengatakan bahwa metode adalah suatu cara yang dipergunakan untuk mencapai tujuan yang telah ditetapkan. ${ }^{18}$

Metode pengajaran adalah cara pelaksanaan dari pada proses pengajaran atau soal bagaimana teknisnya sesuatu bahan pelajaran diberikan. ${ }^{19}$

Dari pengertian diatas, maka metode pembelajaran dapat diartikan suatu ilmu yang memberikan jalan menuju terjadinya pembelajaran atau suatu cara yang dilakukan oleh dosen, agar materi kuliah yang dihasilkannya dapat dengan mudah dipahami, dimengerti oleh mahasiswanya.

b. Indikator Metode

Dari berbagai metode pengajaran, tiada ada satupun yang dapat disebut sebagai metode yang jelek dan metode yang baik. Hal ini disebabkan semuanya mempunyai kebaikan dan kelemahan sendiri-sendiri. Kebaikan atau kebaikan itu bergantung kepada:

1) Jenis bahan yang diberikan;

\footnotetext{
${ }^{14}$ Moh Uzer Usman, Op.Cit., hlm. 92

${ }^{15}$ Ibid., hlm. 29

${ }^{16}$ E. Mulyasa, Standar Kompetensi, Op.Cit., hlm

${ }^{17}$ Sardiman, Am, Op.Cit., hlm. 86

${ }^{18}$ Syaiful Bukri, Strategi Belajar Mengajar, (Jakarta: Rineka Cipta, 1997), hlm. 53

${ }^{19}$ B. Suryo Subroto, Proses Belajar Mengajar di Sekolah, (Jakarta: Rineka Cipta, 1996), hlm. 148
} 
2) Siswa yang dihadapi;

3) Situasi dan kondisi pada waktu proses belajar dan mengajar berlangsung;

4) Tujuan yang akan dicapai;

5) Alat bantu pengajaran yang digunakan. ${ }^{20}$

Indicator metode pembelajaran yang diuraikan ini, belum semuanya dibicarakan, maka yang akan diuraikan antara lain:

1) Metode proyek;

2) Metode eksperimen;

3) Metode tugas dan resitasi

4) Metode diskusi;

5) Metode sosio drama;

6) Metode demonstrasi;

7) Metode problem, solving;

8) Metode Tanya jawab;

9) Metode latihan;

10) Metode ceramah. ${ }^{21}$

\section{Prestasi Belajar}

a. Pengertian

Prestasi adalah hasil yang telah dicapai dari yang telah dilakukan.22 Ali Imron Mengartikan prestasi adalah hasil usaha kegiatan belajar yang dinyatakan dalam bentuk symbol, angka, huruf, maupun kalimat yang dapat mencerminkan hasil yang telah dicapai oleh setiap anak dalam periode tertentu. ${ }^{23}$ Sedangkan menurut Sudjana, prestasi adalah penilaian dari hasil kegiatan/usaha yang telah dilakukan yang dinyatakan dalam bentuk angka atau huruf dan dapat mencerminkan hasil yang dicapai seseorang dalam jangka waktu tertentu. ${ }^{24}$

Prestasi belajar adalah kemampuan seseorang yang telah dicapainya dalam belajar yang tercermin dalam bidang kognitif, dan sensorik motorik..$^{25}$

Dari beberapa pendapat diatas, dapat dipahami bahwa prestasi belajar adalah hasil yang dicapai oleh seseorang telah melakukan kegiatan atau aktivitas belajar. Hasil itu diperoleh karena pada mulanya belum ada. Maka terjadilah proses perubahan dari belum mampu kearah sudah mampu, perubahan itu tentunya terjadi dalam jangka waktu tertentu. Adanya perubahan dalam pola tingkah laku menandakan telah adanya hasil

${ }^{20}$ Subari, Supervisi Pendidikan dalam Rangka Perbaikan Situasi Mengajar, (Jakarta: Bumi Aksara, 1994), hlm. 74

${ }^{21}$ Saiful Bahri Djamarah, Strategi Belajar Mengajar, (Jakarta: Rineka Cipta, 1995), hlm. 93

${ }^{22}$ Ali Imron, Belajar dan Pembelajaran, (Jakarta: Pustaka Jaya, 1996), hlm. 16

${ }^{23}$ WJS. Poerdawarminta, Kamus Umum Bahasa Indonesia, (Jakarta: Balai Pustaka, 1984), hlm. 455.

${ }^{24}$ Nana Sudjana, Pembinaan dan Pengembangan Kurikulum di Sekolah, (Bandung: Sinar Baru AlGensindo, 1996, hlm. 48

${ }^{25}$ WS. Winkel, Psikologi Pengajaran, (Jakarta: Gramedia, 1989), hlm. 50 
belajar. Semakin banyak kemampuan yang diperoleh, maka semakin banyak pula perubahan yang telah terjadi atau dialami.

b. Indikator Prestasi Belajar

Pada prinsipnya, pengungkapan hasil belajar ideal meliputi segenap ranah psikologi yang berubah sebagai akibat pengalaman dan proses belajar siswa. Namun demikian, pengungkapan perubahan tingkah laku seluruh ranah itu, khususnya ranah rasa murid, sangat sulit. Hal ini disebabkan perubahan hasil belajar itu ada yang bersifat intangible (tak dapat diraba). Oleh karena itu, yang dapat dilakukan guru dalam hal ini adalah hanya mengambil cublikan perubahan tingkah laku yang dianggap penting dan diharapkan dapat mencerminkan perubahan yang terjadi sebagai hasil belajar siswa, baik yang berdimensi cipta, dan rasa maupun yang berdimensi karsa.

Kunci pokok untuk memperoleh ukuran dan data hasil belajar siswa sebagaimana yang terurai diatas adalah mengetahui garis-garis besar indicator (petunjuk adanya prestasi tertentu) dikaitkan dengan jenis prestasi yang sedang diungkapkan atau diukur.

Jenis, Indikator, dan Cara

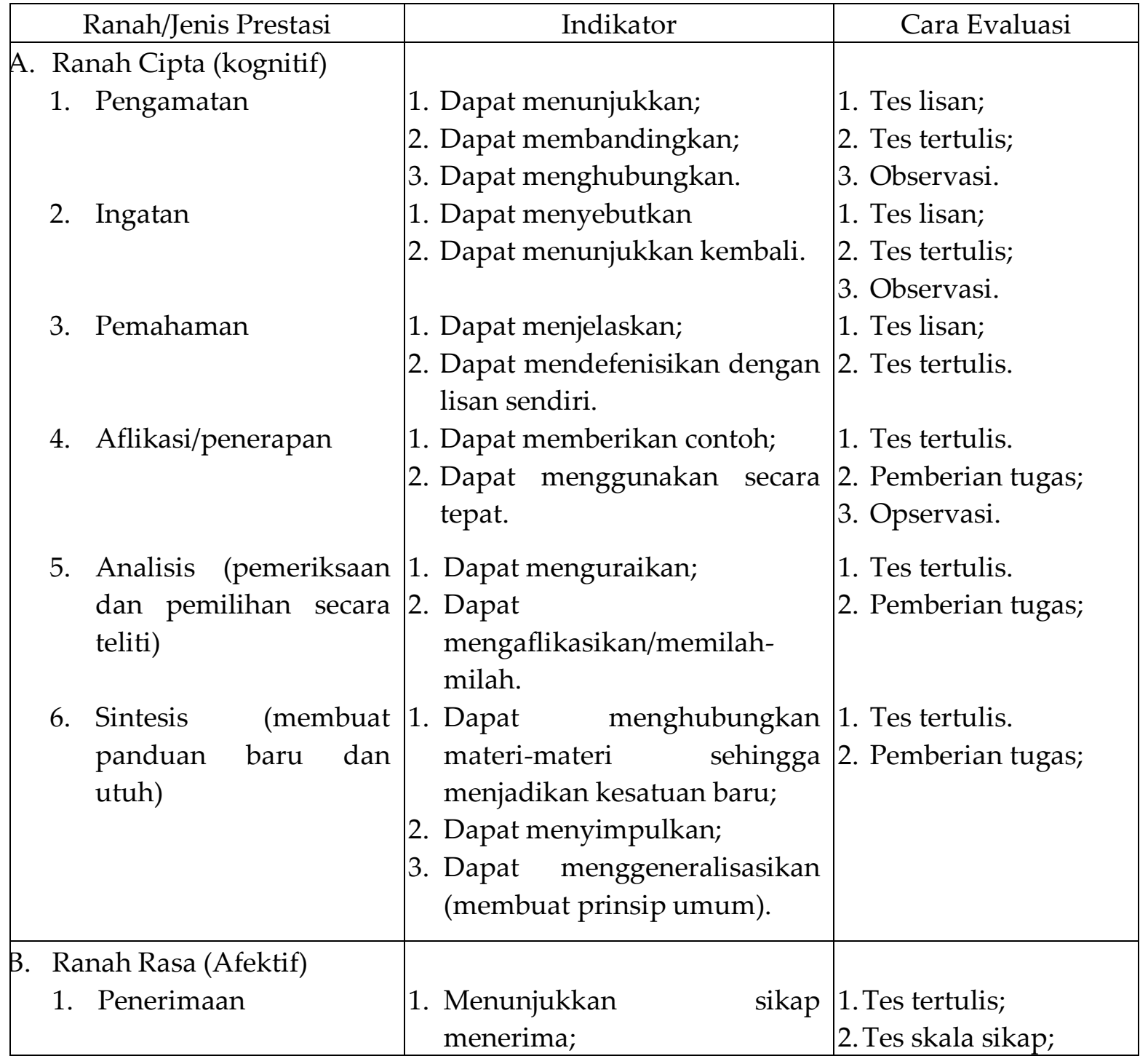




\begin{tabular}{|c|c|c|}
\hline & 2. Menunjukkan sikap menolak. & 3. Observasi. \\
\hline 2. Sambutan & $\begin{array}{l}\text { 1. Kesediaan } \\
\text { berpartisipasi/terlibat; } \\
\text { 2. Kesediaan memanfaatkan. }\end{array}$ & $\begin{array}{l}\text { 1. Tes skala sikap; } \\
\text { 2. Pemberian tugas; } \\
\text { 3. Observasi. }\end{array}$ \\
\hline $\begin{array}{l}\text { 3. Apresiasi } \\
\text { menghargai) }\end{array}$ & $\begin{array}{l}\text { 1. Menganggap penting dan } \\
\text { bermanfaat; } \\
\text { 2. Menganggap indah dan } \\
\text { harmonis; } \\
\text { 3. Mengagumi. }\end{array}$ & $\begin{array}{l}\text { 1. Tes sikap penilaian } \\
\text { sikap; } \\
\text { 2. Pemberian tugas; } \\
\text { 3. Observasi. }\end{array}$ \\
\hline 4. Internalisasi & $\begin{array}{l}\text { 1. Mengakui dan meyakini; } \\
\text { 2. Mengingkari. }\end{array}$ & $\begin{array}{l}\text { 1. Tes skala sikap; } \\
\text { 2. Pemberian tugas } \\
\text { ekspresip (yang } \\
\text { mengatakan sikap) } \\
\text { dan tugas proyektif } \\
\text { (yang menyatakan } \\
\text { perkiraan atau } \\
\text { ramalan) }\end{array}$ \\
\hline $\begin{array}{l}\text { 5. Karakterisasi } \\
\text { (penghayatan) }\end{array}$ & $\begin{array}{l}\text { 1. } \text { Melembagakan atau } \\
\text { meniadakan; } \\
\text { 2. Menjelmakan atau } \\
\text { meniadakan dalam pribadi } \\
\text { dan prilaku sehari-hari. }\end{array}$ & $\begin{array}{ll}\text { 1. } & \text { Pemberian tugas } \\
\text { ekspresif } & \text { dan } \\
\text { proyektif; } & \\
\text { 2. } & \text { Observasi. }\end{array}$ \\
\hline $\begin{array}{l}\text { C. Ranah Karsa (Psikomotor) } \\
\text { 1. Keterampilan bergerak } \\
\text { dan bertindak; }\end{array}$ & $\begin{array}{l}\text { Kecakapan mengkordinasikan } \\
\text { gerakan mata, tangan, kaki dan } \\
\text { anggota tubuh lainnya. }\end{array}$ & $\begin{array}{l}\text { 1. Observasi; } \\
\text { 2. Tes tindakan. }\end{array}$ \\
\hline $\begin{array}{l}\text { 2. Kecakapan ekspresi } \\
\text { verbal dan non-verbal }\end{array}$ & $\begin{array}{l}\text { 1. Kefasihan } \\
\text { melafalkan/mengucapkan; } \\
\text { 2. Kecakapan membuat mimik } \\
\text { dan gerakan jasmani. }\end{array}$ & $\begin{array}{l}\text { 1.Tes lisan; } \\
\text { 2. Observasi; } \\
\text { 3. Tindakan. }^{26}\end{array}$ \\
\hline
\end{tabular}

c. Indikator Keberhasilan

Yang menjadi petunjuk bahwa suatu proses belajar mengajar dianggap berhasil adalah hal-hal:

1) Daya serap terhadap bahan pengajaran yang diajarkan mencapai prestasi tinggi, baik secara individual maupun kelompok.

2) Prilaku yang digariskan dalam tujuan pengajaran/instruksional khusus (TIK) yang telah dicapai oleh siswa, baik secara individual maupun kelompok. ${ }^{27}$

Namun demikian, indicator yang banyak dipakai sebagai tolak ukur keberhasilan adalah daya serap.

\footnotetext{
${ }^{26}$ Sardiman Am., Op.Cit, hlm. 85

${ }^{27}$ Syaiful Bahri Djamarah, Strategi Belajar Mengajar, Op.Cit., hlm. 120
} 
Indicator tentang prestasi ini telah diungkapkan Alex, bahwa anak-anak yang memiliki tingkah laku prestasi pada umumnya menunjukkan empat macam tingkah laku. Yang membedakannya dari anak-anak yang lainnya yaitu:

1) Dalam berbagai macam studi mereka menunjukkan usaha yang kuat untuk selalu menyelesaikan sikap persoalan yang dihadapinya dengan tuntas, cenderung berhasil baik dalam menjalankan tugasnya.

2) Mereka mempunyai rasa kompetensi dan selalu meningkatkan prestasinya.

3) Mereka selalu bersaing dengan temannya dalam berprestasi.

4) Mereka selalu berusaha memperlihatkan hasil belajarnya pada orang tua dan guru dan senang mendapatkan pujian. ${ }^{28}$

\section{METODE PENELITIAN}

Jenis penelitian ini adalah kuantitatif dan desainnya adalah expost facto. Desain expost facto adalah suatu penelitian yang bertujuan untuk menguji apa yang telah terjadi. Pendekatan analisisnya menggunakan pendekatan analisis deskriptif kuantitatif yaitu menggambarkan apa adanya tentang atau suatu variable melalui angka-angka, dengan mengkorelasikan antara dua variable, yaitu variable bebas dan variable terikat. Penetapan sampel penelitian ini berdasarkan propesi strata atau stratifled sample. ${ }^{29}$ Maka jumlah sampel yang diambil adalah 45 orang dari mahasiswa dan 3 orang dari dosen mata kuliah hadis. Variable penelitian ini terdiri dari variable $X$ dan variable $Y$, variable $X$ yaitu variable bebas, variable ini ada dua komponen yaitu motivasi dan metode. Sedangkan Y adalah variable terikat yaitu prestasi (nilai) belajar dalam mata kuliah hadis. Dalam penelitian ini instrument yang digunakan untuk mengumpulkan data adalah observasi, interview, angket dan studi dokumen. Data ini dianalisis dengan menggunakan teknik analisis product moment dan regresi sederhana untuk mengetahui pengaruh motivasi dari dosen terhadap prestasi mata kuliah hadis dan mengetahui pengaruh metode mengajar dosen terhadap prestasi mata kuliah hadis.

Adapun rumus korelasi product moment adalah:

$$
r x y=\frac{\mathrm{N} \cdot \sum \mathrm{x}_{1} \mathrm{y}-\left(\sum \mathrm{x}_{1}\right)\left(\sum \mathrm{y}\right)}{\sqrt{\left.\left(N \cdot \sum x_{1}{ }^{2}\right)-\left(\sum x_{1}\right)^{2}\right)\left(N \cdot \sum y^{2}-\left(\sum y\right)^{2}\right.}}
$$

\section{HASIL PENELITIAN DAN PEMBAHASAN}

1. Deskripsi Data

Deskripsi data mengenai variabel motivasi dari dosen, metode mengajar dosen dan prestasi mata kuliah Hadits, secara berturut-turut di uraikan kepada bagian berikut ini:

${ }^{28}$ Alex Sobur, Anak Masa Depan, (Bandung: Aksara, 1986), hlm. 61

${ }^{29}$ Suharsimi Arikunto, Op.Cit., hlm. 125 
a. Motivasi dari dosen

Dari penelitian yang dilakukan terhadap responden, diperoleh data motivasi dari dosen adalah sebagaimana yang terdapat pada table berikut ini:

Tabel 1

Deskripsi Data Motivasi dari Dosen

\begin{tabular}{|c|c|c|}
\hline No & Statistik & Skor \\
\hline 1 & Skort Tertinggi & 90 \\
\hline 2 & Skor Terendah & 44 \\
\hline 3 & Mean & 70 \\
\hline 4 & Median & 72 \\
\hline 5 & Modus & 66 \\
\hline 6 & Standar Deviasi & 10,3 \\
\hline
\end{tabular}

Gambar data secara lengkap dapat dilihat pada tebel dan gambar berikut ini:

Tabel 2

Distribusi Frekuensi Motivasi dari Dosen

\begin{tabular}{|c|c|c|c|}
\hline Kelas Interval & Fo & \%fo & $\% f k$ \\
\hline $86-92$ & 3 & $5 \%$ & $100 \%$ \\
\hline $79-85$ & 10 & $16.67 \%$ & $95 \%$ \\
\hline $72-78$ & 19 & $31.67 \%$ & $78.33 \%$ \\
\hline $65-71$ & 13 & $21.67 \%$ & $46.66 \%$ \\
\hline $58-64$ & 7 & $11.67 \%$ & $24.99 \%$ \\
\hline $51-57$ & 5 & $8.33 \%$ & $13.32 \%$ \\
\hline $44-50$ & 3 & $5 \%$ & $5 \%$ \\
\hline Total & 60 & 100,00 & \\
\hline
\end{tabular}

\section{MOTIVASI}

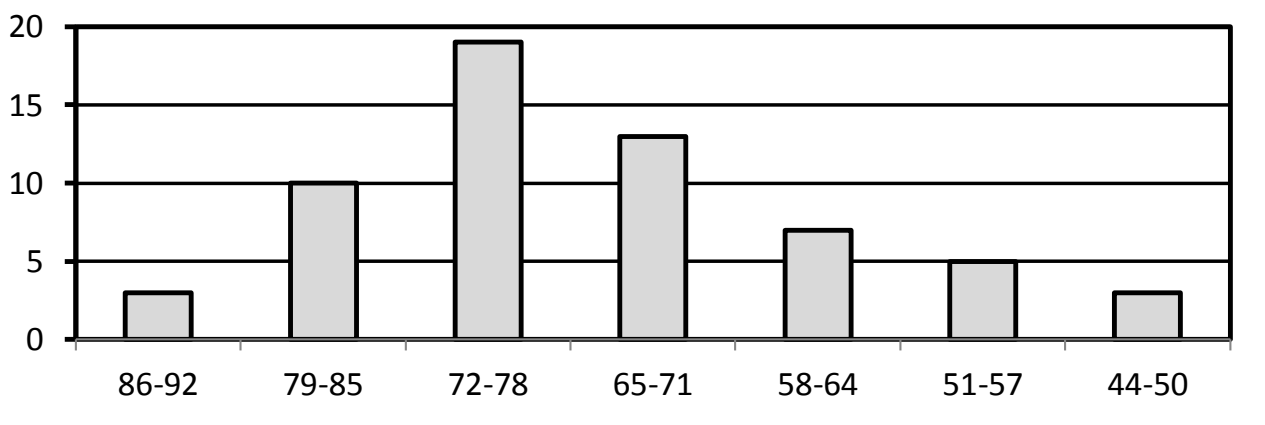

Gambar 1. Histogram Skor Motivasi dari Dosen

Dalam mengidentifikasi tingkat kecenderungan Variabel Motivasi dari Dosen dapat dikatakan bahwa Motivasi dari Dosen masuk dalam kategori cukup yaitu $73 \%$ dari skor ideal. (Lihat lampiran 4) 
b. Metode Mengajar Dosen

Dari penelitian yang dilakukan terhadap responden, diperoleh data metode mengajar dosen adalah sebagaimana yang terdapat pada table 3 berikut ini:

Table 3

Rangkuman Deskripsi Data Skor

Metode Mengajar Dosen

\begin{tabular}{|c|c|c|}
\hline No & Statistik & Skor \\
\hline 1 & Skort Tertinggi & 44 \\
\hline 2 & Skor Terendah & 24 \\
\hline 3 & Mean & 35 \\
\hline 4 & Median & 35 \\
\hline 5 & Modus & 38 \\
\hline 6 & Standar Deviasi & 5 \\
\hline
\end{tabular}

Dari data tersebut menunjukkan rata-rata (mean) dan modus dengan median tidak jauh berbeda, hal ini menggambarkan bahwa distribusi frekuensi skor variabel metode mengajar dosen datanya cenderung berdistribusi normal.

Gambar data secara lengkap data dilihat pada table dan gambar berikut ini:

Table 4

Distribusi Frekuensi Metode Mengajar Dosen

\begin{tabular}{|c|c|c|c|}
\hline Kelas Interval & Fo & \%fo & \%fk \\
\hline $42-44$ & 7 & 11,67 & 100 \\
\hline $39-41$ & 8 & 13,33 & 88,33 \\
\hline $36-38$ & 14 & 23,33 & 75 \\
\hline $33-35$ & 10 & 16,67 & 51,67 \\
\hline $30-32$ & 13 & 21,67 & 35 \\
\hline $27-29$ & 6 & 10 & 13,33 \\
\hline $24-26$ & 2 & 3,33 & 3,33 \\
\hline Total & 60 & 100,00 & \\
\hline
\end{tabular}

\section{METODE MENGAJAR DOSEN}

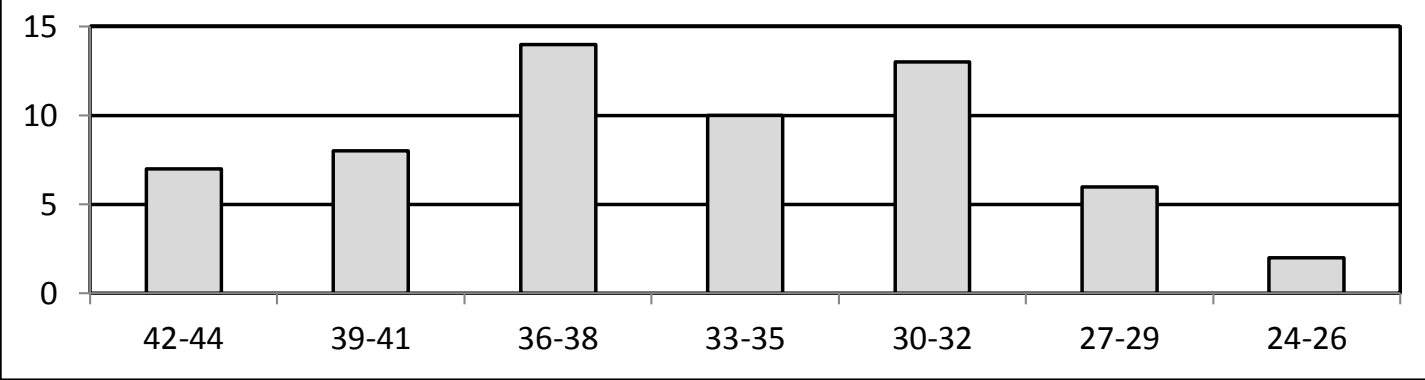

Gambar 2: Histogram Skor Variabel Metode Mengajar Dosen 
Dalam mengidentifikasi tingkat kecenderungan variabel metode mengajar dosen dapat dikatakan bahwa metode mengajar dosen masuk dalam kategori cukup yaitu 73\% dari skor ideal.(Lihat lampiran)

c. Prestasi Mata Kuliah Hadits

Dari penelitian yang dilakukan terhadap responden, diperoleh data prestasi mata kuliah Hadits adalah sebagaimana yang terdapt pada table 5 berikut ini:

Table 5

Rangkuman Deskripsi Data Skor Prestasi Mata Kuliah Hadits

\begin{tabular}{|c|c|c|}
\hline No & Statistik & Skor \\
\hline 1 & Skort Tertinggi & 86 \\
\hline 2 & Skor Terendah & 69 \\
\hline 3 & Mean & 77 \\
\hline 4 & Median & 77 \\
\hline 5 & Modus & 76 \\
\hline 6 & Standar Deviasi & 3,98 \\
\hline
\end{tabular}

Data tersebut menunjukkan rata-rata (mean) dan modus dengan median tidak jauh berbeda, hal ini menggambarkan bahwa distribusi frekuensi skor variabel motivasi belajar siswa datanya cenderung berdistribusi normal. Gambaran data secara lengkap dapat dilihat pada table dan gambar berikut.

Table 6

Rangkuman Deskripsi Data Skor Prestasi Mata Kuliah Hadits

\begin{tabular}{|c|c|c|c|}
\hline Kelas Interval & Fo & $\%$ fo & $\%$ fk \\
\hline $84-86$ & 3 & $5 \%$ & $100 \%$ \\
\hline $81-83$ & 8 & $13,33 \%$ & $95 \%$ \\
\hline $78-80$ & 12 & $20 \%$ & $81,67 \%$ \\
\hline $75-77$ & 19 & $31,67 \%$ & $61,67 \%$ \\
\hline $72-74$ & 13 & $21,67 \%$ & $30 \%$ \\
\hline $69-71$ & 5 & $8,33 \%$ & $8,33 \%$ \\
\hline Total & 60 & 100,00 & \\
\hline
\end{tabular}

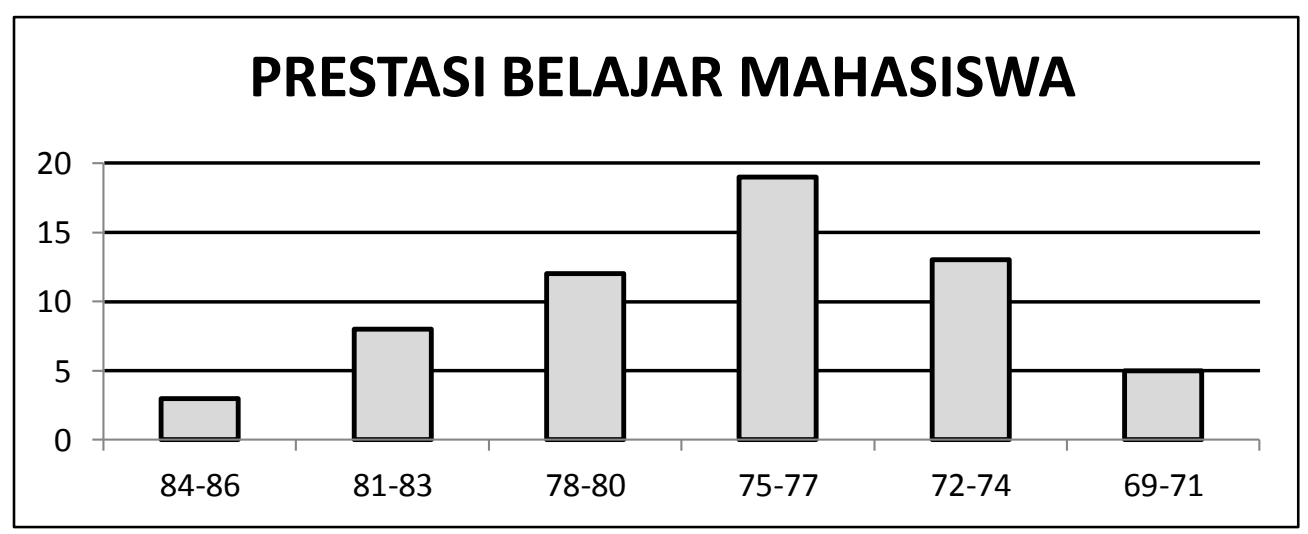

Gambar 2: Histogram Skor Variabel Prestasi Mata Kuliah Hadits 
Dalam mengidentifikasi tingkat kecenderungan variabel Prestasi mata kuliah hadits dapat dikatakan bahwa prestasi mata kuliah hadits masuk dalam kategori Baik yaitu rata dapat nilai B $(76,75)$. (Lihat lampiran 4)

2. Uji Persyaratan Analisis

Pengujian hipotesis dalam penelitian ini dilakukan dengan analisis korelasi dan regresi. Untuk menggunakan tehnik ini ada persyaratan yang harus dipenuhi diantaranya menurut Sudjana, adalah: 1) data bersumber dari sampel yang dipilih secara acak, 2) data berasal dari populasi yang berdistribusi normal, dan 3) sebaran datanya linear.

a. Data diperoleh secara acak

Prosedur pengambilan sampel secara acak telah dilakukan sewaktu memilih sampel dengan menggunakan tehnik "random sampling". Dalam penelitian ini sampel diambil dari sampel secara acak.

b. Uji Normalitas

Untuk melihat normal tidaknya data melalui grafik di bawah ini, yaitu dengan memperhatikan sebaran data (titik-titik) pada sumbu diagonal grafik tersebut dan pemgambilan keputusan sesuai dengan ketentuan berikut:

* Jika data (titik) menyebar disekitar garis diagonal dan mengikuti arah garis diagonal, maka model registrasi memenuhi asumsi normalitas.

* Jika data (titik) menyebar jauh dari garis diagonal dan/atau tidak mengikuti arah garis diagonal, maka model regresi tidak memenuhi asumsi normalitas.

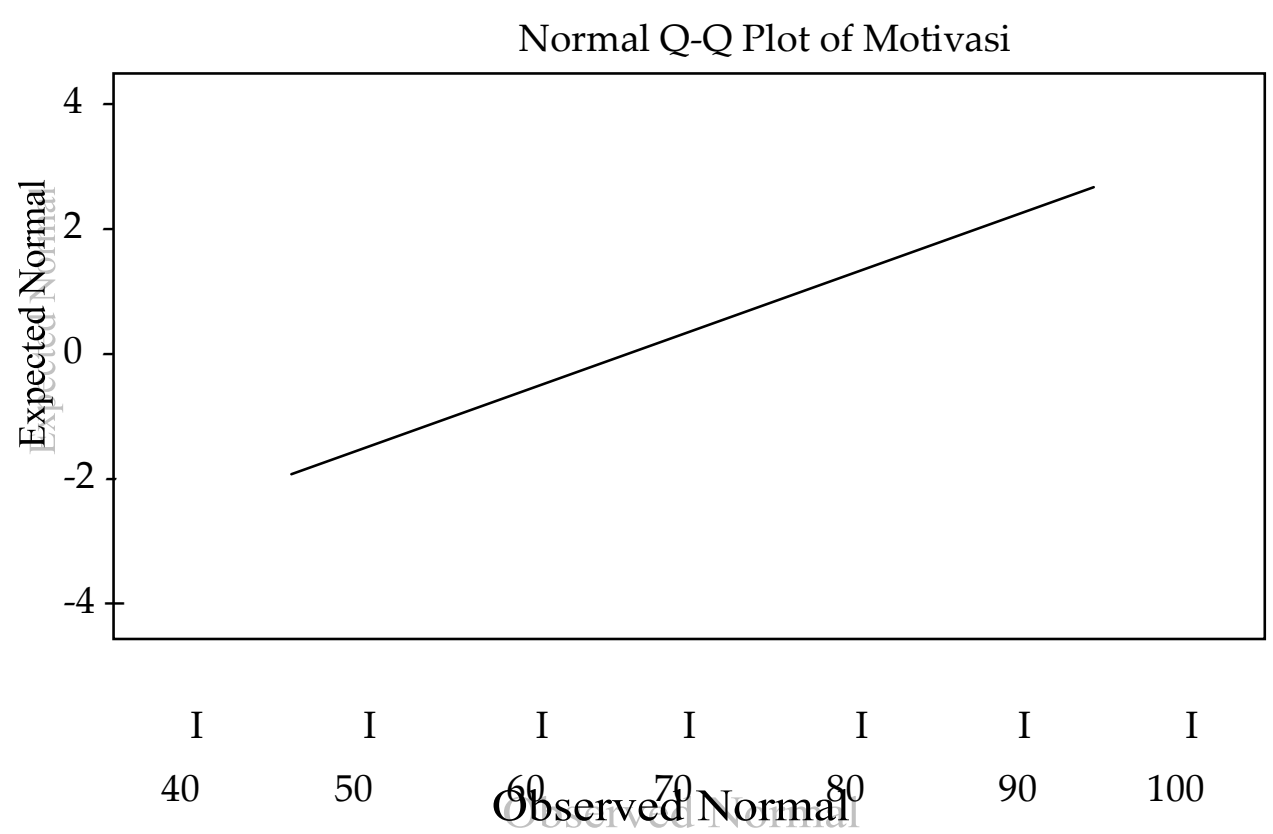

Gambar 4: Grafik Uji Normalitas Variabel Motivasi dari Dosen 


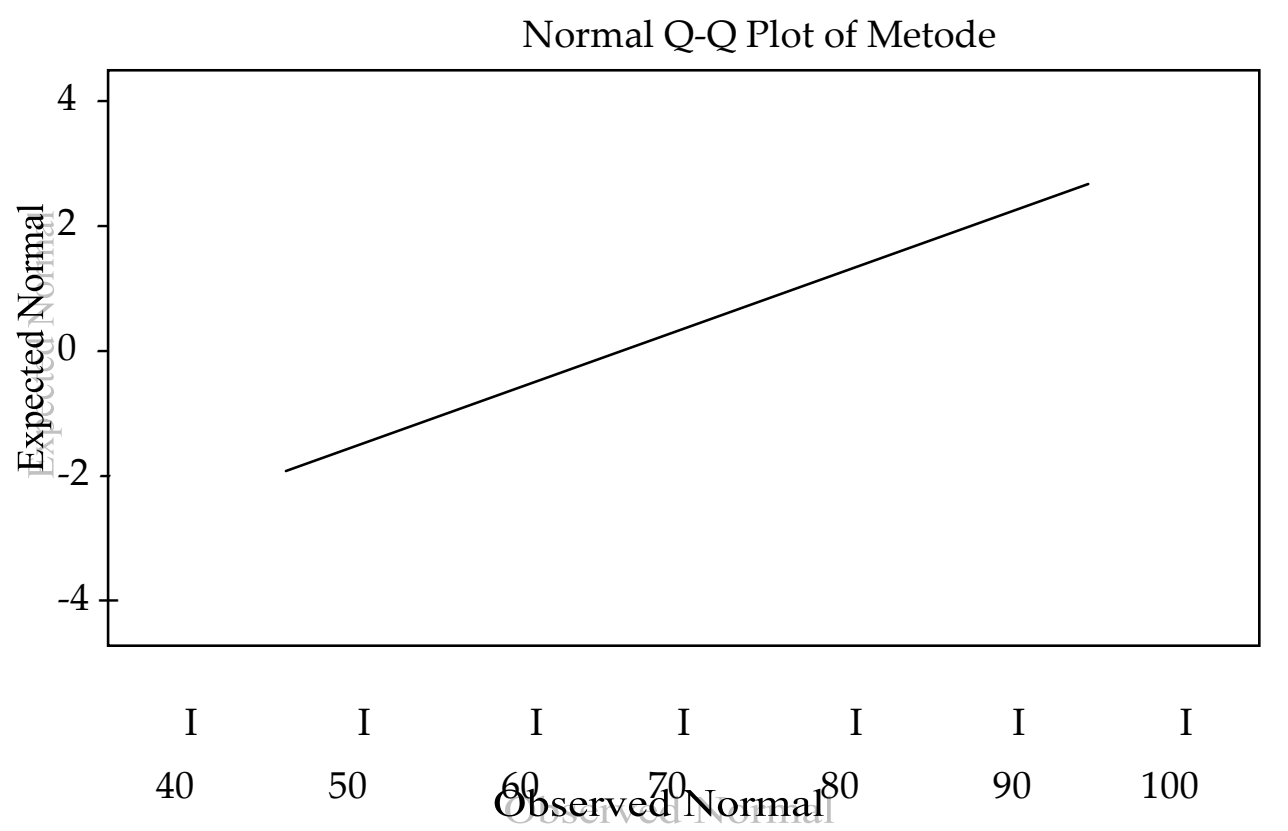

Gambar 5: Grafik Uji Normalitas Variabel Motivasi dari Dosen

Normal Q-Q Plot of Prestasi

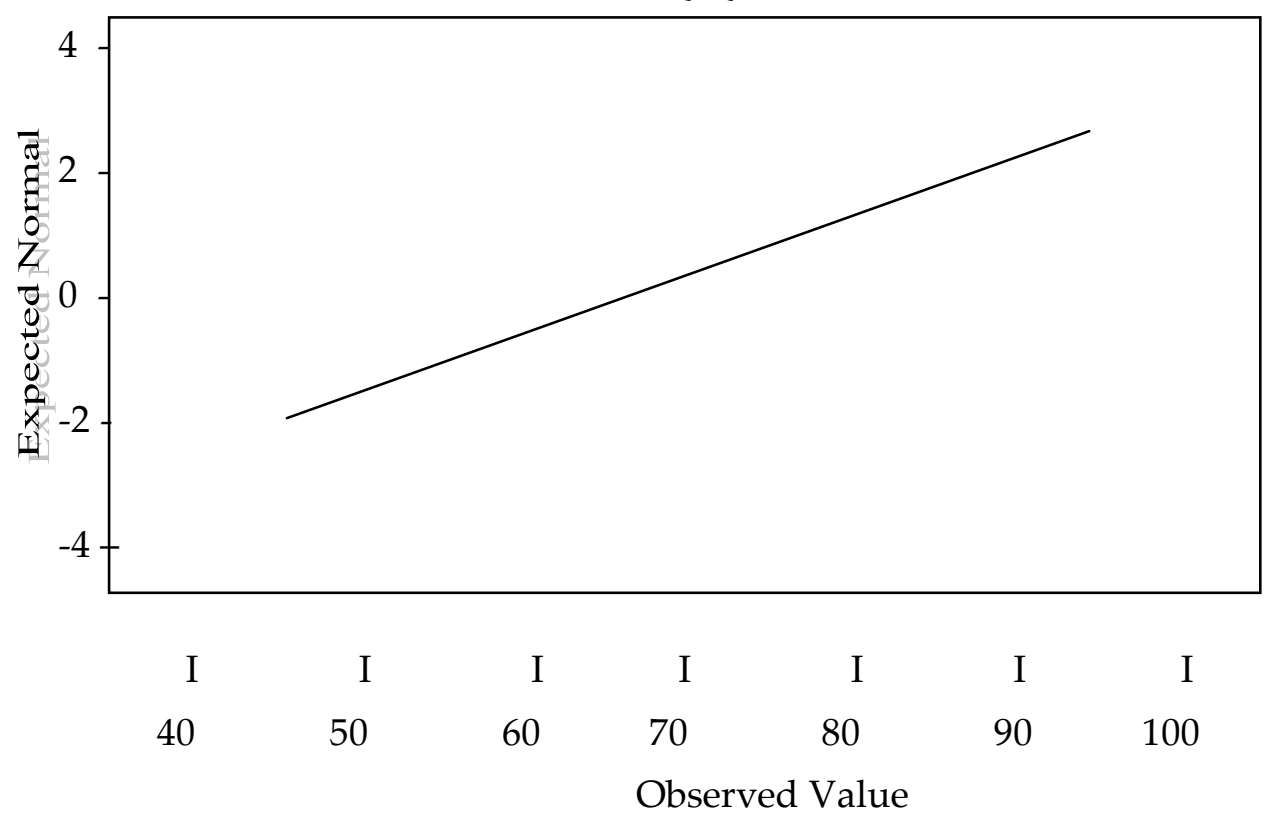

Gambar 6: Grafik Uji Normalitas Variabel Prestasi Mata Kuliah Hadits

Dari grafik yang tergambar diatas dapat dilihat bahwa pada umumnya data (titik) menyebar disekitar garis diagonal serta mengikuti arah garis. Maka data tersebut bias disimpulkan berdistribusi normal, sehingga model regresi layak dipakai untuk memprediksi variabel terikat berdasarkan masukan variabel indepedennya.

c. Uji Linieritas

Uji linieritas dilakukan dalam persamaan regresi antara variabel bebas dengan variabel terikat. Dalam hal ini yang akan diuji yakni variabel motivasi dari dosen, metode mengajar dosen dan prestasi mata kuliah Hadits. Data dianalisa 
dengan menggunakan ANOVA dan uji signifikansi garis regresi dengan melihat nilai p. setelah dilaksanakan perhitungan dengan program SPSS versi 12,0 maka diperoleh:

1) Hasil perhitungan untuk variabel motivasi dari dosen $\left(X_{1}\right)$ dengan prestasi mata kuliah Hadits $(Y)$, diperoleh $F_{\text {hitung }}=11,165$ dan nilai $p=0,01$. Sebagai criteria linearitas, apabila $p<0,05$, maka korelasi antara variabel bebas dengan terikat adalah linier. Berdasarkan criteria tersebut maka dapat disimpulkan bahwa variabel motivasi dari dosen $\left(\mathrm{X}_{1}\right)$ dengan prestasi mata kuliah hadits $(\mathrm{Y})$ adalah linier.

2) Hasil perhitungan yang variabel metode mengajar dosen $\left(X_{2}\right)$ dengan prestasi mata kuliah Hadits ( $Y$ ), diperoleh $F$ hitung $=11,698$ dan nilai $\mathrm{p}=0,001$ sebagai criteria linieritas, apabila $\mathrm{p}<0,05$, maka korelasi antara variabel bebas dengan terikat adalah linier. Berdasarkan criteria tersebut maka dapat disimpulkan bahwa variabel metode mengajar dosen $\left(\mathrm{X}_{2}\right)$ dengan prestasi mata kuliah Hadits (Y) adalah linier. (lihat lampiran 6)

3. Pengajuan Hipotesis

a. Interpretasi Hasil Pengujian Hipotesis Pertama

Hipotesis pertama dalam penelitian ini adalah "Ada pengaruh motivasi dari dosen dengan prestasi mata kuliah hadits".

Terdapat atau tidaknya hubungan variabel motivasi dari dosen $\left(X_{1}\right)$ dengan prestasi mata kuliah Hadits $(Y)$ digunakan analisis korelasi sederhana. Besarnya pengaruh antara variabel motivasi dari dosen dengan prestasi mata kuliah Hadits (r) sebesar 0,402. Hal ini menunjukkan ada pengaruh antara motivasi dari dosen dengan prestasi mata kuliah Hadits. Sedangkan tingkat signifikasi koefisien korelasi dai out put (diukur dari probabilitas) menghasilkan angka 0,001. Karena probabilitas jauh di bawah 0,05 maka pengaruh antara motivasi dari dosen dengan prestasi mata kuliha Hadits signifikan. Hasil perhitungannya sebagai berikut:

Tabel 7

\begin{tabular}{|c|c|c|c|}
\multicolumn{4}{|c}{ Rangkuman Hasil Analisis Korelasi $\mathrm{X}_{1}$ dan Y } \\
\hline Korelasi & $\begin{array}{c}\text { Koefisien Korelasi } \\
(r)\end{array}$ & $\begin{array}{c}\text { Koefisien Determinasi } \\
(r 2)\end{array}$ & Probabilitas \\
\hline $\mathrm{r}_{\mathrm{y} 1}$ & 0,402 & 0,1616 & 0,01 \\
\hline
\end{tabular}

Table diatas menunjukkan bahwa koefisien korelasi antara variabel motivasi dari dosen dengan prestasi mata kuliah Hadits ialah positif dengan koefisien korelasi $\left(\mathrm{rx}_{1 \mathrm{y}}\right)=0,402$, kekuatan hubungan ditunjukkan dengan koefisien determinasi $\mathrm{r}^{2}=0,1616$ dengan sumbangan $0,1616 \times 100 \%=16,16 \%$ 
Untuk mengetahui bentuk hubungan $\mathrm{X}_{1}$ dengan $\mathrm{Y}$ prediktif atau tidak, dilakukan analisis regresi linear sederhana. Dari hasil perhitungan diperoleh persamaan regresi $\breve{\Upsilon}=\mathrm{a}+\mathrm{b} \quad X_{1}=\breve{\Upsilon}=65,81+0,155 X_{1}$. Konstanta sebesar 65,81 menyatakan bahwa jika tidak ada kenaikan nilai dari variabel persepsi siswa tentang motivasi dari dosen $\left(\mathrm{X}_{1}\right)$, maka nilai prestasi mata kuliah hadits (Y) adalah 65,81. Koefisien regresi sebesar 0, 155 mentakan bahwa setiap penambahan (karena ada tanda tambah +) satu skor atau nilai motivasi dari dosen akan memberikan peningkatan sebesar 0,155. Hasil uji keberartian dan kelinieran persamaan regresi sederhana dapat dilihat pada lampiran 9 dari table berikut:

Tabel 8

Resume Perhitungan Regresi $\mathrm{X}_{1}$ dengan $\mathrm{Y}$

ANOVA (b)

\begin{tabular}{|c|l|l|l|l|c|c|}
\hline Mode & & \multicolumn{1}{|c|}{$\begin{array}{c}\text { Sum of } \\
\text { Squarres }\end{array}$} & \multicolumn{1}{|c|}{$\mathrm{df}$} & $\begin{array}{c}\text { Mean } \\
\text { Square }\end{array}$ & $\mathrm{F}$ & Sig \\
\hline 1 & Regresion & 151.297 & 1 & 151.297 & 11.165 & ,001(a) \\
\hline & Residual & 785.953 & 58 & 13.551 & & \\
\hline & Total & 937.250 & 59 & & & \\
\hline
\end{tabular}

a. Prodictors : (Constant), Motivasi

b. Dependent Variabel : Prestasi

\begin{tabular}{|c|c|c|c|c|c|c|}
\hline Model & & $\begin{array}{c}\text { Cnstandardized } \\
\text { Coefficients }\end{array}$ & $\begin{array}{c}\text { Standardized } \\
\text { Coefficients }\end{array}$ & $t$ & Sig \\
\hline & & B & Std. Error & Beta & & \\
\hline 1 & (Constant) & 65.815 & 3.307 & & 19.902 &, 000 \\
& MOTIVASI &, 155 &, 946 &, 402 & 3.341 &, 001 \\
\hline
\end{tabular}

a. Dependent Variabel: PRESTASI

Dari lampiran tersebut kelihatan bahwa hasil perhitungan uji keberartian persamaan regresi sederhana diperoleh $F_{\text {hitung }}=11,165$ dengan signifikansi 0,001. Karena taraf signifikansi ada di bawah 0,005, ini berarti persamaan regresi sederhana $\breve{\Upsilon}=65,81+0,155 X_{1}$ adalah sangat berarti untuk memprediksi $Y$.

Berdasarkan analisis diatas dapat disimpulkan bahwa motivasi dari dosen mempunyai hubungan prediktif yang sangat signifikan dengan nilai prestasi mata kuliah Hadits. Hal ini menunjukkan bahwa hipotesis pertama penelitian ini'"' ada pengaruh yang signifikan antara motivasi dari dosen dengan nilai prestasi mata kuliah Hadits" telah teruji secata empiris.

b. Interpretasi Hasil Pengujian Hipotesis Kedua

Hipotesis kedua dalam penelitian ini adalah "ada pengaruh metode mengajar dosen dengan prestasi mata kuliah Hadits". 
Terdapat atau tidaknya hubungan variabel metode mengajar dosen $\left(\mathrm{X}_{2}\right)$ dengan prestasi mata kuliah Hadits $(Y)$ digunakan analisis korelasi sederhana. Besarnya pengaruh antara variabel metode mengajar dosen dengan prestasi mata kuliah Hadits (r) sebesar 0,410. Hal ini menunjukkan ada pengaruh antara metode mengajar dosen dengan prestasi mata kuliah Hadits. Sedangkan tingkat signifikansi koefisien korelasi dari out put (diukur dari probabilitas) menghasilkan angka 0,001. Karena probabilitas jauh di bawah 0,005 maka pengaruh antara metode menajar dosen dengan prestasi mata kuliah Hadits signifikan. Hasil perhitungannya sebagai berikut:

Tabel 9

Rangkuman Hasil Analisis Korelasi $\mathrm{X}_{2}$ dengan $\mathrm{Y}$

\begin{tabular}{|c|c|c|c|}
\hline Korelasi & $\begin{array}{c}\text { Koefisien Korelasi } \\
(r)\end{array}$ & $\begin{array}{c}\text { Koefisien Determinasi } \\
(r 2)\end{array}$ & Probabilitas \\
\hline $\mathrm{r}_{\mathrm{y} 1}$ & 0,410 & 0,1681 & 0,01 \\
\hline
\end{tabular}

Table diatas menunjukkan bahwa koefisien korelasi antara variable metode mengajar dosen dengan prestasi mata kuliah Hadits aialah positif dengan koefisien korelasi $\left(\mathrm{rx}_{2 \mathrm{y}}\right)=0,410$, kekuatan hubungan ditunjukkan dengan koefisien determinasi $\mathrm{r}^{2}=0,1618$ dengan sumbangan $0,1618 \times 100 \%=16,18 \%$.

Untuk mengetahui bentuk hubungan $\mathrm{X}_{2}$ dengan $\mathrm{Y}$ prediktif atau tidak, dilakukan analisis regresi linear sederhana. Dari hasil perhitungan diperoleh persamaan regresi $\breve{\Upsilon}=a+b X_{2}=\breve{\Upsilon}=65,28+0,326 X_{2}$. Dari variable persepsi siswa tentang motivasi dari dosen $\left(\mathrm{X}_{2}\right)$, maka nilai prestasi mata kuliah Hadits $(\mathrm{Y})$ adalah 65,28 . Koefisien regresi sebesar 0,326 menyatakan bahwa setiap penambahan (karena ada tanda tambah +) satu skor atau nilai metode mengajar dosen akan memberikan peningkatan sebesar 0,326. Hasil uji keberartian dan kelinieran persamaan regresi sederhana dapat dilihat ada lampiran 9 dan table berikut:

Table 10

Resume Perhitungan Regresi $X_{2}$ dengan $Y$

\begin{tabular}{|l|l|l|l|c|c|c|}
\hline \multirow{2}{*}{ Model } & & $\begin{array}{c}\text { Sum of } \\
\text { Squares }\end{array}$ & df & $\begin{array}{c}\text { Mean } \\
\text { Square }\end{array}$ & F & Sig \\
\hline 1 & $\begin{array}{l}\text { Regresi } \\
\text { on }\end{array}$ & 157.302 & 1 & 157.302 & 11,698 &, $001(\mathrm{a})$ \\
\hline & Residual & 779,948 & 58 & 13,447 & & \\
\hline & Total & 937,250 & 59 & & & \\
\hline
\end{tabular}

a. Predictors: (Constant), METODE

b. Dependent Variable: PRESTASI 
Coefficients (a)

\begin{tabular}{|c|c|c|c|c|c|c|}
\hline \multirow{2}{*}{ Model } & & \multicolumn{2}{|c|}{$\begin{array}{c}\text { Unstandardized } \\
\text { Coefficients }\end{array}$} & $\begin{array}{c}\text { Sandardizad } \\
\text { Coefficients }\end{array}$ & \multirow{2}{*}{$\mathrm{t}$} & \multirow{2}{*}{ Sig } \\
\cline { 3 - 6 } & & $\mathrm{B}$ & $\begin{array}{c}\text { Std. } \\
\text { Error }\end{array}$ & Beta & & \\
\hline 1 & $\begin{array}{c}\text { (Constant } \\
\text { ) }\end{array}$ & 65.284 & 3.386 & & 19.282 &, 000 \\
\hline & Metode &, 326 &, 095 &, 410 & 3.420 &, 001 \\
\hline
\end{tabular}

a. Dependent Variable: PRESTASI

Dari table diatas kelihatan bahwa hasil perhitungan uji keberartian persamaan regresi sederhana diperoleh $F_{\text {hit }}=11,698$ dengan signifikansi 0,0001. Karena taraf signifikansi ada di bawah 0,005, ini berarti persamaan regresi sederhana $\breve{\Upsilon}=65,28+0,326 \mathrm{X}_{2}$ adalah sangat berarti untuk memprediksi $\mathrm{Y}$.

Berdasarkan analisis diatas dapat disimpulkan bahwa motivasi dari dosen mempunyai hubungan prediktif yang sangat signifikan dengan nilai prestasi mata kuliah Hadits. Hal ini menunjukkan bahwa hipotesis kedua penelitian ini 'ada pengaruh yang signifikan antara metode mengajar dosen dengan prestasi mata kuliha Hadits' telah teruji secara empiris.

c. Interpretasi Hasil Pengujian Hipotesis Ketiga

Hipotesis ketiga penelitian ini adalah "Ada pengaruh yang signifikan antara metode mengajar dosen dengan prestasi mata kuliha Hadits".

Besarnya hubungan dengan sumbangan variable motivasi dari dosen $\left(\mathrm{X}_{1}\right)$ dan metode mengajar dosen $\left(X_{1}\right)$ secara bersama-sama terhadap variable prestasi mata kuliah Haidits $(\mathrm{Y})$ dapat diketahui dengan menggunakan anaisis korelasi ganda. Analisis ini bertujuan untuk mengetahui apakah hubungan antara variable itu berupa hubungan prediktif atau tidak, sedangkan keberartiannya dapat diketahui dengan uji " $\mathrm{F}$ ". hasil analisis korelasi ganda dan uji keberartian koefisien korelasinya dapat dilihat pada lampiran 10 dan table berikut:

\begin{tabular}{|c|c|c|c|c|c|}
\hline \multirow{2}{*}{ Korelasi } & \multirow{2}{*}{$\begin{array}{c}\text { Koefisien } \\
\text { Korelasi } \\
\end{array}$} & $\begin{array}{c}\text { Koefisien } \\
\text { Determinasi } \\
\end{array}$ & $(R)$ & $F_{\text {hit }}$ & \multicolumn{2}{|c|}{$F_{\text {tabel }}$} \\
\cline { 5 - 6 } & $\left(R^{2}\right)$ & & $\alpha=0,05$ & $\alpha=0,01$ \\
\hline$r_{\mathrm{y} 1.2}$ & 0,475 & 0,2256 & 12,26 & 3,146 & 4,998 \\
\hline
\end{tabular}

Hasil analis pada table diatas menunjukkan bahwa koefisien korelasi ganda antara variable motivasi dan metode mengajar dosen secara bersama-sama terhadap prestasi mata kuliha Hadits $\left(R_{x 1 x 2 y}\right)$ yaitu 0,475 , setelah dilakukan uji $\mathrm{F}$ ternyata $\mathrm{F}_{\text {hit }}=12,26$ sedangkan $\mathrm{F}_{\text {tabel }}=3,146$ dengan $\alpha=0,05$ dan 4,998 dengan $\alpha=0$, 01, ternyata $F_{h i t}>$ dari $F_{\text {tabel }}$ berarti koefisien korelasi ganda tersebut sangat signifikan. 
Koefisien determinasi menunjukkan bahwa sumbangan motivasi dan metode mengajar dosen secara bersama-sama terhadap prestasi mata kuliah Hadits sebesar $0,2256 \times 100 \%=22,56 \%$ dan sisanya sebesar $77,44 \%$ diperkirakan berasal dari variable-variabel dari yang tidak termasuk dalam penelitian ini. Berdasarkan analisis diatas dapat disimpulkan bahwa motivasi dan metode mengajar dosen secara bersam-sama mempunyai pengaruh terhadap prestasi mata kuliah hadits. Maka hipotesis ketiga dalam penelitian ini "ada pengaruh yang signifikan antara motivasi dan metode mengajar dosen secara bersama-sam terhadap prestasi mata kuliah Hadits" telah teruji secara empiris.

Selanjutnya dapat dinyatakan bahwa hubungan ganda variable bebas terhadap variable terikat berbentuk hubungan prediktif dengan persamaan prediksi $\breve{\Upsilon}=61,4+0,105 X_{1}+0,227 X_{2}$. Sedangakan $F_{h i t}=8,303>F_{(2,57)(0,05)}=3,146$ dan $\mathrm{F}_{(2,57)(0,01)}=4,998$, berarti persamaan regresi ganda adalah sangat signifikan.

\section{PENUTUP}

Dari hasil temuan penelitian ini dapat dilihat bahwa motivasi dari dosen dan metode mengajar dosen baik secara sendiri-sendiri maupun secara bersama-sama mempunyai pengaruh terhadap prestasi mata kuliah Hadits. Hal tersebut terlihat dari hasil uji statistik yang dilakukan, sehingga dapat dikatakan bahwa hipotesis yang menyatakan bahwa terdapat hubungan yang signifikan antara motivasi dari dosen dengan metode mengajar baik secara sendiri maupun bersama-sama dengan hasil belajar mata kuliah Hadist mahasiswa IAIN Padangsidimpuan. 
110 Tazkir Vol. 02 No. 1 Januari-Juni 2016

\section{DAFTAR RUJUKAN}

Bukri, Syaiful, Strategi Belajar Mengajar, Jakarta: Rineka Cipta, 1997.

Djamarah, Saiful Bahri, Strategi Belajar Mengajar, Jakarta: Rineka Cipta, 1995.

E. Mulyasa, Guru Profesional Menciptakan Pembelajaran Kreatif dan Menyenangkan, Bandung: Remaja Rosda Karya, 2007.

E. Mulyasa, Standar Kompetensi dan Sertifikasi Guru, Bandung: Remaja Rosda Karya, 2007.

Imron, Ali, Belajar dan Pembelajaran, Jakarta: Pustaka Jaya, 1996.

S. Nasution, Didaktik Asas-asas Mengajar, Bandung: Jammars, 1982.

Sardiman, Interaksi dan Motivasi Belajar Mengajar, Jakarta: Grafindi Persada, 2004.

Sobur, Alex, Anak Masa Depan, Bandung: Aksara, 1986.

Subari, Supervisi Pendidikan dalam Rangka Perbaikan Situasi Mengajar, Jakarta: Bumi Aksara, 1994.

Subroto, B. Suryo, Proses Belajar Mengajar di Sekolah, Jakarta: Rineka Cipta, 1996.

Sudjana, Nana, Pembinaan dan Pengembangan Kurikulum di Sekolah, Bandung: Sinar Baru AlGensindo, 1996.

Usman, Moh Uzer, Didaktik Asas-asas Mengajar, Bandung: Remaja Rosda Karya, 2000.

WJS. Poerdawarminta, Kamus Umum Bahasa Indonesia, Jakarta: Balai Pustaka, 1984.

WS. Winkel, Psikologi Pengajaran, Jakarta: Gramedia, 1989. 